\title{
PENGEMBANGAN MODEL PENDIDIKAN KARAKTER MELALUI GERAKAN LITERASI SEKOLAH BERBASIS FILM
}

\author{
Farida Nugrahani, Mukti Widayati, Ali Imron A.M. \\ MPBI Program Pascasarjana Universitas Veteran Bangun Nusantara Sukoharjo \\ PBSI FKIP Universitas Muhammadiyah Surakarta \\ farida.nugrahani01@gmail.com
}

Diterima: 31 Desember 2018

Publikasi: 27 Februari 2019

DOI: http://dx.doi.org/10.32528/bb.v4i1.1865

\begin{abstract}
ABSTRAK
Tujuan Penelitian ini adalah untuk mengembangkan model pendidikan karakter melalui gerakan literasi sekolah (GLS) berbasis film. Model itu dikembangkan melalui empat tahap mengikuti Plomp (1997), meliputi (1) pengkajian awal, (2) perancangan, (3) realisasi (konstruksi), (4) validasi dan revisi. Penelitian dimulai dengan pengamatan kondisi faktual di lapangan, dan pengkajian teori berkaitan dengan pendidikan karakter, literasi, dan film. Selanjutnya dilakukan perencanaan model dan realisasinya melalui penetapan komponen sintaks, sistem sosial, sistem pendukung, dampak instruksional dan pengiringnya. Setelah itu dilakukan validasi dan revisi model dengan meminta pertimbangan ahli dan praktisi pendidikan di lapangan. Hasil penelitian menunjukkan bahwa model pendidikan karakter yang dikembangkan dalam penelitian ini dapat diwujudkan dalam bentuk buku Panduan pendidikan karakter melalui GLS berbasis film yang bersifat valid, praktis dan efektif untuk diterapkan dalam meningkatkan kualitas Pendidikan Karakter di sekolah. Panduan itu memuat (1) latar belakang, pengertian, tujuan, ruang lingkup, sasaran, dan target; (2) tahapan pendidikan karakter melalui GLS di Sekolah Dasar; (3) pelaksanaannya pada tahap pembiasaan; (4) pelaksanaannya pada tahap pengembangan; (5) pelaksanaannya pada tahap pembelajaran; dan (6) Penutup. Buku panduan yang dikembangkan ini telah di uji cobakan di Sekolah Dasar Negeri Pengkol 1 Kabupaten Sukoharjo dan diterbitkan dengan ber ISBN.
\end{abstract}

Kata kunci: Pendidikan karakter, Gerakan Literasi Sekolah, film.

\begin{abstract}
The purpose of this study was to develop a character education model through filmbased school literacy movements. The model was developed through four stages following Plomp (1997), including (1) initial assessment, (2) design, (3) realization (construction), (4) validation and revision. The research began with the observation of factual conditions in the field, and the study of theories related to character education, literature, and film. Then the model planning and realization was carried out through the determination of syntax components, social systems, support systems, instructional and accompanied impacts. After that, validation and revision of the model were carried out by consulting experts and education practitioners in the field. The results showed that the character education model developed in this study could be implemented in the form of a character education guide book through film-based school literacy movements that is valid, practical and effective to be applied in improving the quality of Character Education in schools. The guide book contained (1) background, description, goals, scope, objectives and targets; (2) stages of character education
\end{abstract}


through film-based school literacy movements in Elementary School; (3) implementation in the habituation stage; (4) implementation at the development stage; (5) implementation at the learning stage; and (6) Closing. This guidebook had been tested in Pengkol 1 Public Elementary School, Sukoharjo Regency and published with ISBN.

Keywords: Character education, School Literacy Movement, film.

\section{PENDAHULUAN}

Dalam percaturan dunia, bangsa Indonesia belum dihargai sebagai bangsa yang maju, berbudaya dan berkarakter. Fakta di lapangan menunjukkan bahwa karakter bangsa Indonesia pada umumnya memang masih rendah dan bahkan cenderung menurun atau memudar. Memudarnya karakter itu ditandai dengan adanya perilaku antisosial dan amoral yang banyak ditemukan di tengah-tengah masyarakat. Hal itu salah satu indikator bagi belum berhasilnya pendidikan karakter di sekolah dewasa ini (Lapsley \& Yeager 2013).

Perilaku masyarakat Indonesia yang tidak berkarakter dapat disaksikan melalui tayangan televisi pada setiap harinya, baik perilaku yang ditunjukkan oleh pejabat pemerintah, politisi, pengusaha, akademisi, artis, maupun rakyat jelata. Hal itu sangat membuat prihatin siapa saja yang memiliki komitmen terhadap masa depan bangsa ini.

Mengingat pentingnya karakter bagi harga diri, nama baik dan jati diri bangsa, maka pendidikan karakter perlu diperhatikan secara serius, agar efektif pelaksanaannya sedini mungkin. Utamanya adalah pembentukan karakter generasi muda sebagai penerus bangsa, melalui jalur pendidikan formal dari jenjang sekolah yang paling rendah hingga jenjang yang tertinggi.

Menanggapi fenomena empiris tentang perilaku masyarakat yang menunjukkan lemahnya karakter bangsa Indonesia itu, maka sangat penting untuk dilakukan upaya bagi perbaikannya, sejak dini, melalui jenjang sekolah yang paling rendah, yaitu Sekolah Dasar. Dalam konteks ini adalah pelaksanaan program pendidikan karakter melalui program Gerakan Literasi Sekolah berbasis film (Faizah dkk 2016). Kegiatan tersebut antara lain, mengenal literasi dengan menonton film pada waktu sebelum jam pelajaran mulai atau pada waktu jeda jam pelajaran di sekolah. Melalui pemanfaatan waktu 15 menit sebelum belajar untuk kegiatan literasi berbasis film ini diharapkan, dapat bermanfaat bagi pembentukan karakter anak sesuai yang diharapkan oleh sekolah (Dirjen Dikdasmen 2016). Melalui penelitian ini dikembangkan model pendidikan karakter melalui Gerakan Literasi Sekolah (GLS) berbasis film yang bersifat praktis, valid dan efektif untuk diimplementasikan di SD.

Film merupakan materi yang diminati siswa dalam pendidikan karakter. Film yang dibuat berdasarkan novel sastra sangat digemari masyarakat, 
karena itu sangat efektif dimanfaatkan untuk mendukung GLS (Istadiyantha \& Wati 2015). Film yang dibuat berdasarkan novel sastra itu merupakan karya lama yang muncul kembali dengan wajah baru (Graffy 2011). Sebuah novel yang tebal dan baru selesai dibaca dalam beberapa hari jika difilmkan, dapat dinikmati dalam waktu yang relatif singkat (Ardianto 2014). Meskipun tentu saja, dalam bentuk filmnya ada pengurangan dari bagian aslinya(Stam \& Raengo 2008).

Film yang diangkat dari novel sastra sering disebut dengan istlah ekranisasi sastra. Ekranisasi sastra ini dapat difungsikan sebagai media sekaligus materi dalam pendidikan karakter (Suseno 2013)(Ardianto 2014). Mengingat bahwa, selain tampilannya indah, film juga banyak memuat nilai-nilai luhur kemanusiaan yang bagus untuk membentuk karakter seseorang (Uricchio 2014). Melalui film (ekranisasi) sastra, siswa dapat terdorong untuk berperilaku dan berkarakter sebagaimana para tokoh dalam film yang ditontonnya (Sugeng Riyadi 2014) (Karkono 2009).

Berkaitan dengan program pendidikan karakter ini, Kemendikbud telah mengembangkan program GLS yang melibatkan semua warga sekolah dan masyarakat, sebagai bagian dari ekosistem dalam pendidikan karakter. Program GLS ini muncul atas kesadaran pemerintah terhadap rendahnya kompetensi anak Indonesia, yang tercatat dalam PIRLS 2011 International Results in Reading, menduduki peringkat ke-45 dari
48 negara. Sementara dalam uji literasi membaca PISA 2009, Indonesia menduduki peringkat ke-57, dan dalam PISA 2012 menduduki peringkat ke-64 (Dirjen Dikdasmen 2016). Dengan rendahnya peringkat kompetensi anak Indonesia itu, maka dikembangkanlah GLS berdasarkan agenda Nawacita, yang terkait erat dengan komponen literasi sebagai modal pembentukan sumber daya manusia berkualitas, produktif dan berkarakter.

Untuk itu, melalui dokumen resmi Kemendiknas (2010), dirumuskan 18 nilai karakter sebagai panduan dalam pendidikan karakter di Indonesia, yang meliputi karakter berikut: (1) religius; (2) jujur, (3) toleransi, (4) disiplin, (5) kerja keras, (6) kreatif, (7) mandiri, (8) demokratif, (9) rasa ingin tahu, (10) semangat kebangsaan, (11) cinta tanah air, (12) menghargai prestasi, (13) komunikatif, (14) cinta damai, (15) gemar membaca, (16) peduli lingkungan, (17) peduli sosial, dan (18) tanggung jawab.

Dalam proses pelaksanaan program pendidikan karakter itu, sangat diperlukan adanya tahapan-tahapan. Tahapan itu dimulai dengan pemahaman, dan penanaman nilai-nilai karakter, dan dilanjutkan dengan impementasinya melalui pembiasaan, dan pembudayaan, agar nilai-nilai karakter yang dituju dapat tercermin dalam sikap dan perilaku sehari-hari para siswa (Manullang 2013)(Davidson 2014).

Pendidikan karakter merupakan sebuah proses panjang, yaitu proses pembelajaran untuk menumbuhkan nilai 
luhur, budi pekerti akhlak mulia yang berakar pada ajaran agama, adatistiadat dan nilai-nilai yang kepribadian (Vardani 2018). Tujuannya agar anak tumbuh menjadi manusia yang bermartabat, dan menjadi warga bangsa yang berkarakter sesuai dengan nilainilai luhur bangsa dan agama.

Diharapkan melalui GLS berbasis film di SD itulah, siswa berkesempatan yang luas untuk dapat menemukan karakternya melalui kegiatan dalam suasana santai, menyenangkan, dan di luar jam pelajaran.

\section{METODE PENELITIAN}

Penelitian ini termasuk dalam jenis penelitian dengan pendekatan penelitian pengembangan. Objeknya adalah model pendidikan karakter melalui GLS berbasis film yang valid, praktis dan efektif untuk digunakan dalam pendidikan karakter di SD. Fokus penelitiannya adalah pengembangan buku Panduan Pendidikan karakter melalui GLS berbasis film. Rancangan penelitian ini mengikuti model Plomp (1997:12), yang dilakukan melalui empat tahapan, meliputi pengkajian awal, perancangan, realisasi/ konstruksi, tes/ evaluasi dan revisi.

Tahapan awal dalam penelitian ini dimulai dengan pengamatan kondisi faktual di lapangan, dan pengkajian teori. Langkah berikutnya adalah melakukan perancangan model pendidikan karakter ini melalui pengorganisasian materi literasi berbasis film, serta penyusunan instrumennya.

Tahap selanjutnya, dilakukan realisasi model melalui penetapan komponen, meliputi sintaks, sistem sosial, sistem pendukung, dampak instruksional dan pengiring. Berikutnya, dilakukan validasi dan revisi model dengan meminta pertimbangan ahli dan praktisi di lapangan. Pada tahap validasi dan revisi dilakukan pengulangan, sampai diperoleh prototipe model yang memenuhi persyaratan valid, praktis dan efektif. Hasil validasi dan revisi dari tahap ini selanjutnya disebut dengan prototipe 1 .

Selanjutnya, dilakukan uji coba di lapangan, untuk memperoleh prototipe 2 , dan demikian seterusnya sampai mendapatkan prototipe sesuai model yang diinginkan.

Luaran yang diharapkan dari penelitian ini adalah tersusunnya buku panduan pendidikan karakter melalui GLS berbasis film di SD. Untuk keperluan itu prototipe yang telah dikembangkan diujicobakan kepada siswa SD N Pengkol 1 Kabupaten Sukoharjo sebagai subjek penelitiannya.

Secara umum untuk memperoleh prototipe model yang final, dilakukan berbagai tahapan seperti yang telah diuraikan di atas. Prototipe 1, 2, 3, dan selanjutnya merupakan suatu kesinambungan, karena masing-masing prototipe yang lebih kemudian itu merupakan penyempurnaan dan perbaikan dari prototipe-prototipe yang tersusun pada tahapan sebelumnya, dan terus dilakukan sampai mendapatkan prototipe final, yaitu berupa buku Panduan pendidikan arakter melalui GLS berbasis Film yang inovatif, praktis, dan efektif untuk diterapkan dalam pendidikan karakter di Sekolah Dasar. 
Gambar 1.

Bagan Pengembangan Model

Pendidikan Karakter melalui GLS Berbasis

Film

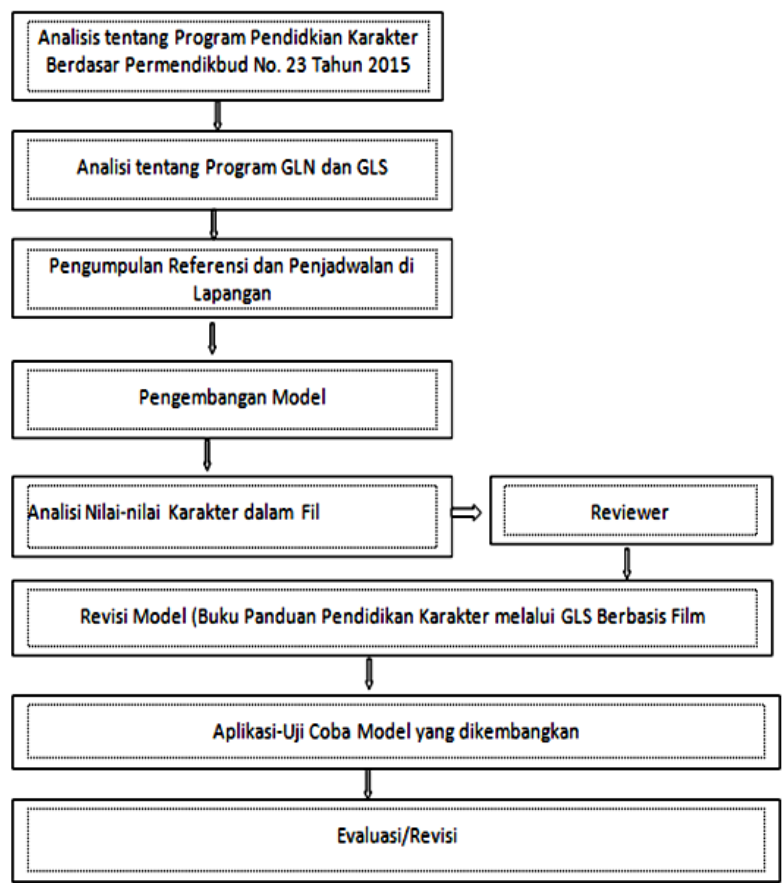

Data dan berbagai sumber data yang diperlukan dalam penelitian ini adalah sebagai berikut. (1) Untuk mengetahui validitas konstruksi dari buku panduan yang disusun diperlukan penilaian para pakar pendidikan dan praktisi di lapangan. (2) Untuk mengetahui tingkat kepraktisan buku panduan yang disusun diperlukan sumber data pakar dan praktisi yang menyatakan bahwa buku panduan yang disusun dapat diterapkan dalam pendidikan karakter di sekolah. (3) Untuk memperoleh data tentang tingkat keefektifan buku panduan yang disusun, diperlukan pengamatan terhadap aktifitas siswa dan guru selama proses pendidikan karakter di sekolah melalui GLS, respon siswa dalam mengikuti GLS dan karakter yang terbentuk pada siswa setelah mengikuti program dengan model yang dikembangkan.

Analisis kevalidan, kepraktisan dan keefektipan buku panduan pendidikan karakter melalui GLS berbasis film ini dilakukan dengan cara sebagai berikut.

Analisis Kevalidan dilakukan dengan mencari rata-rata dari penilaian validator. Skor rata-rata validator (V) dikonfirmasikan dengan interval penentuan kategori validitas model dengan kriteria yang terdapat pada tabel 1 berikut.

Tabel 1

Kriteria untuk Analisis Kevalidan

\begin{tabular}{|l|l|l|}
\hline No & Interval Skor & \multicolumn{1}{|c|}{ Kategori } \\
\hline 1 & $\mathrm{~V}<1,5$ & tidak valid \\
\hline 2 & $1,5 \leq \mathrm{V}<2,5$ & kurang valid \\
\hline 3 & $2,5 \leq \mathrm{V}<3,5$ & cukup valid \\
\hline 4 & $3,5 \leq \mathrm{V}<4,5$ & valid \\
\hline 5 & $4,5 \leq \mathrm{V}$ & sangat valid \\
\hline
\end{tabular}

Analisis Kepraktisan dilakukan melalui analisis Kelayakan dan Keterlaksanaan. Analisis kelayakan ini dilakukan dengan cara mencari rata-rata dari penilaian validator. Skor rata-rata validator (L) dikonfirmasikan dengan interval penentu kelayakan seperti interval skor yang disampaikan pada tabel 2 berikut ini.

Tabel 2

Kriteria untuk Analisis Kelayakan

\begin{tabular}{|l|l|l|}
\hline No & Interval Skor & \multicolumn{1}{|c|}{ Kategori } \\
\hline 1 & $\mathrm{~L}<1,5$ & $\begin{array}{l}\text { sangat tidak } \\
\text { layak }\end{array}$ \\
\hline 2 & $1,5 \leq \mathrm{L}<2,5$ & kurang layak \\
\hline 3 & $2,5 \leq \mathrm{L}<, 5$ & cukup layak \\
\hline 4 & $3,5 \leq \mathrm{L}<4,5$ & layak \\
\hline 5 & $4,5 \leq \mathrm{L}$ & sangat layak \\
\hline
\end{tabular}

Analisis keterlaksanan dilakukan dengan cara mencari rata-rata dari skor 
observer $(\mathrm{T})$ yang dikonfirmasikan dengan interval penentu keterlaksanaan penerapan model yang dikembangkan, dengan Kriteria interval skor sebagai berikut

Tabel 3

Kriteria untuk Analisis Kelayakan

\begin{tabular}{|l|l|l|}
\hline No & Interval Nilai & Kategori \\
\hline 1 & $\mathrm{~T}<1,5$ & $\begin{array}{l}\text { tidak } \\
\text { terlaksana }\end{array}$ \\
\hline 2 & $1,5 \leq \mathrm{T}<2,5$ & $\begin{array}{l}\text { sebagian kecil } \\
\text { terlaksana }\end{array}$ \\
\hline 3 & $2,5 \leq \mathrm{T}<, 5$ & $\begin{array}{l}\text { separuh } \\
\text { terlaksana }\end{array}$ \\
\hline 4 & $3,5 \leq \mathrm{T}<4,5$ & terlaksana \\
\hline 5 & $4,5 \leq \mathrm{T}$ & $\begin{array}{l}\text { seluruhnya } \\
\text { terlaksana }\end{array}$ \\
\hline
\end{tabular}

Analisis Keefektivan model dilakukan melalui analisis hasil capaian karakter positif pada siswa setelah mengikuti program GLS dengan panduan yang dikembangkan, dan respon siswa selama mengikuti program. Analisis hasil capaian karakter positif pada siswa dilihat melalui pengamatan dan jawaban siswa pada kuesioner yang disampaikan. Respon siswa dilihat melalui antusiasme siswa selama mengikuti program. Model yang dikembangkan ini dikatakan efektif jika minimal $80 \%$ siswa menunjukkan karakter yang positif dan memberikan respon yang posistif pula.

\section{HASIL DAN PEMBAHASAN}

\section{a. Buku Panduan GLS Berbasis Literasi yang Dikembangkan}

Sesuai dengan masalah dan tujuan dalam penelitan ini, maka hasil penelitian dikelompokkan dalam tiga bagian, meliputi: (1) pengembangan model pendidikan karakter melalui GLS berbasis film; (2) hasil uji validitas, efektivitas dan kepraktisan penerapan model yang dikembangkan; dan (3) nilai-nilai karakter yang dapat dikembangkan melalui program GLS berbasis film ini.

Model yang dikembangkan dalam penelitian ini diwujudkan dalam bentuk buku panduan pendidikan karakter melalui GLS berbasis film. Keseluruhan isi buku panduan itu adalah sebagai berikut. (1) Pendahuan yang memuat tentang latar belakang, pengertian, tujuan, ruang lingku, sasaran, dan target pencapaian pelaksanan GLS di SD; (2) Tahapan gerakan literasi sekolah di SD; (3) Pelaksanaan GLS pada tahap pembiasaan; (4) Pelaksanaan GLS pada tahap pengembangan; (5) Pelaksanaan GLS pada tahap pembelajaran; (6) Penutup. Buku panduan GLS itu merupakan buku petunjuk untuk guru sebagai pedoman dalam proses kegiatan literasi dalam rangka pendidikan karakter di sekolah.

\section{b. Hasil Validasi terhadap Kualitas Model yang dikembangkan}

Berikut ini disajikan hasil validasi pakar terhadap kualitas buku Panduan GLS berbasis film yang dikembangkan berdasarkan kriteria aspek, bentuk atau format, dan kesesuaian isi buku dengan tujuan serta kebermanfaatannya terhadap Pendidikan karakter di Sekolah Dasar. 
Tabel 4

Penilaian Kevalidan Buku Panduan Pendidikan Karakter yang Dikembangkan

\begin{tabular}{|c|l|l|l|}
\hline No. & \multicolumn{1}{|c|}{ Indikator } & $\begin{array}{l}\text { Skor } \\
\text { Rata } \\
\text { rata }\end{array}$ & Kategori \\
\hline 1 & $\begin{array}{l}\text { Sistematika dan } \\
\text { format buku } \\
\text { bersifat konsisten } \\
\text { dan sesuai standar. }\end{array}$ & 3,61 & Valid \\
\hline 2 & $\begin{array}{l}\text { Isi buku panduan } \\
\text { menunjang } \\
\text { pencapaian tujuan. }\end{array}$ & 3,53 & Valid \\
\hline 3 & $\begin{array}{l}\text { Bahasa Indonesia } \\
\text { yang digunakan } \\
\text { bersifat baku, } \\
\text { runtut, efektif, dan } \\
\text { komunikatif, }\end{array}$ & 3,45 & Valid \\
\hline 4 & $\begin{array}{l}\text { Tata tulisnya } \\
\text { bertaaf azaz pada } \\
\text { Pedoman Umum } \\
\text { Ejaan Bahasa } \\
\text { Indonesia (PUEBI). }\end{array}$ & 3,67 & Valid \\
\hline 5 & $\begin{array}{l}\text { Terdapat petunjuk } \\
\text { yang jelas tentang } \\
\text { impementasi, } \\
\text { monitoring dan } \\
\text { evaluasinya. }\end{array}$ & 3,62 & Valid \\
\hline
\end{tabular}

Tabel 5

Penilaian Kelayakan Buku Panduan Pendidikan Karakter yang Dikembangkan

\begin{tabular}{|c|l|c|l|}
\hline No. & \multicolumn{1}{|c|}{ Indikator } & $\begin{array}{c}\text { Skor } \\
\text { Rata } \\
\text { rata }\end{array}$ & Kategori \\
\hline 1 & $\begin{array}{l}\text { Terdapat deskripsi } \\
\text { tentang peran } \\
\text { Kepala Sekolah, } \\
\text { guru, siswa, dan }\end{array}$ & 3,5 & Layak \\
\hline
\end{tabular}

\begin{tabular}{|c|l|l|l|}
\hline & $\begin{array}{l}\text { semua warga } \\
\text { sekolah dalam } \\
\text { pendidikan } \\
\text { karakter. }\end{array}$ & 3,43 & $\begin{array}{l}\text { Cukup } \\
\text { Layak }\end{array}$ \\
\hline 2 & $\begin{array}{l}\text { Tampilan buku itu } \\
\text { menarik. }\end{array}$ & 3,60 & Layak \\
\hline 3 & $\begin{array}{l}\text { Isi buku itu } \\
\text { menarik. }\end{array}$ & $\begin{array}{l}\text { Layak } \\
\text { dengan runtut } \\
\text { sehingga mudah } \\
\text { dipahami. }\end{array}$ & $\begin{array}{l}\text { Bentuk dan ukuran } \\
\text { buku bersifat } \\
\text { praktis sehingga } \\
\text { mudah untuk di } \\
\text { bawa atau dibaca. }\end{array}$ \\
\hline 5 & 3,43 & $\begin{array}{l}\text { Cukup } \\
\text { Layak }\end{array}$ \\
\hline
\end{tabular}

Tabel 6

Penilaian Keterlaksanaan Buku Panduan

Pendidikan Karakter yang Dikembangkan

\begin{tabular}{|c|l|l|l|}
\hline No. & \multicolumn{1}{|c|}{ Indikator } & $\begin{array}{l}\text { Skor } \\
\text { Rata } \\
\text { rata }\end{array}$ & Kategori \\
\hline 1 & $\begin{array}{l}\text { Siswa merespon } \\
\text { positif terhadap } \\
\text { program yang } \\
\text { dilaksanakan } \\
\text { berdasarkan buku } \\
\text { panduan itu. }\end{array}$ & 3,36 & $\begin{array}{l}\text { Cukup } \\
\text { Layak }\end{array}$ \\
\hline 2 & $\begin{array}{l}\text { Siswa aktif dalam } \\
\text { program yang } \\
\text { dilaksanakan } \\
\text { berdasarkan buku } \\
\text { panduan itu. }\end{array}$ & 3,42 & $\begin{array}{l}\text { Cukup } \\
\text { Layak }\end{array}$ \\
\hline 3 & $\begin{array}{l}\text { Siswa termotivasi } \\
\text { untuk mengikuti } \\
\text { program yang } \\
\text { dilaksanakan } \\
\text { berdasarkan buku } \\
\text { panduan itu. }\end{array}$ & 3,63 & Layak \\
\hline 4 & $\begin{array}{l}\text { Siswa gembira } \\
\text { dalam mengikuti } \\
\text { program yang } \\
\text { dilaksanakan } \\
\text { berdasarkan buku } \\
\text { panduan itu. }\end{array}$ & 3,52 & Layak \\
\hline
\end{tabular}




\begin{tabular}{|c|l|l|l|}
\hline 5 & $\begin{array}{l}\text { Guru dapat } \\
\text { menerapkan buku } \\
\text { panduan itu dengan } \\
\text { baik di sekolah. }\end{array}$ & 3,55 & Layak \\
\hline
\end{tabular}

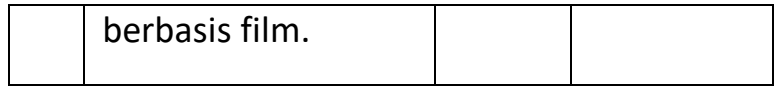

Tabel 7

Penilaian terhadap Keefektifan Buku Pendidikan Karakter yang Dikembangkan

\begin{tabular}{|c|l|l|l|}
\hline No. & \multicolumn{1}{|c|}{ Indikator } & $\begin{array}{l}\text { Skor } \\
\text { Rata } \\
\text { rata }\end{array}$ & Kategori \\
\hline 1 & $\begin{array}{l}\text { Buku panduan itu } \\
\text { berpotensi dalam } \\
\text { meningkatkan mutu } \\
\text { Pendidikan } \\
\text { karakter. }\end{array}$ & 3,5 & Terlaksana \\
\hline 2 & $\begin{array}{l}\text { Buku panduan itu } \\
\text { membantu siswa } \\
\text { dalam menemukan } \\
\text { karakternya. }\end{array}$ & 3,5 & Terlaksana \\
\hline 3 & $\begin{array}{l}\text { Buku panduan itu } \\
\text { membantu guru } \\
\text { dalam } \\
\text { melaksanakan } \\
\text { pendidikan karakter } \\
\text { melalui program } \\
\text { GLS berbasis film di } \\
\text { sekolah. }\end{array}$ & 3,6 & Terlaksana \\
\hline 4 & $\begin{array}{l}\text { Melalui penerapan } \\
\text { buku panduan itu, } \\
\text { dapat } \\
\text { dideskripsikan } \\
\text { karakter yang dituju } \\
\text { dalam program GLS } \\
\text { berbasis film. }\end{array}$ & 3,6 & $\begin{array}{l}\text { Terlaksana } \\
\text { sapwa melalui } \\
\text { program GLS } \\
\text { dideskripsikan } \\
\text { buku panduan itu, }\end{array}$ \\
\hline $\begin{array}{l}\text { Melalui penerapan } \\
\text { dapat }\end{array}$ & 3,4 & Terlaksana \\
\hline
\end{tabular}

c. Nilai-nilai Karakter yang dapat dituju melalui Model yang Dikembangkan

Dalam penelitian ini, contoh film yang digunakan dalam kegiatan literasi di sekolah adalah film Laskar Pelangi (LP) yang skenarionya ditulis oleh Salman Aristo, dan disutradarai oleh Riri Reza, serta diproduksi oleh Miles Film.

Film LP ini sukses besar di pasaran dan disaksikan oleh banyak penonton, sehingga merupakan film box office. Film ini diangkat dari sebuah novel karya Andrea Hirata (2006) yang termasuk dalam kategori novel best seller pada tahun 2006-2007. Sebagaimana filmnya, novel itu juga sangat digemari oleh banyak kalangan. Karena populernya, maka film yang dibuat denganjudul yang sama dengan novel tersebut banyak digemari pula oleh penontonnya. Oleh karena itu, fi mini menjadi sangat terkenal dalam dunia pendiikan karena sangat inspiratif. Atas dasar alasan itulah maka fim ini dipilih dalam program literasi berbasis film di sekolah.

Melalui film LP yang merupakan ekranisasi dari novelnya, penonton dapat menyaksikan visualisasi cerita dalam novel yang menggambarkan kemiskinan masyarakat Belitong dengan berbagai permasalahannya. Namun dalam masyarakat yang miskin itu, ada 
sekelompok anak yang tetap semangat dalam memperjuangkan nasib masa depannya melalui sekolah di desa yang minim fasilitas, dan tidak layak sebagai sekolah. Sekelompok anak itulah yang disebut oleh gurunya sebagai laskar pelangi, yang akhirnya menjadi judul novel dan filmnya.

Film LP itu, telah memberikan inspirasi kepada masyarakat untuk mengembangkan karakter yang terpuji, sesuai pilar-pilar dalam pendidikan karakter yang saling terkait, yaitu (1) rasa tanggung jawab (responsibility), (2) rasa hormat (respect), (3) keadilan (fairness), (4) keberanian (courage), (5) kejujuran (honesty), (6) kewarganegaraan (citizenship), (7) disiplin diri (self disipline), (8) kepedulian (caring), (9) ketekunan (perceverance) (Sudrajat 2011).

Melalui visualisasi gambar dan dialog para pemeran tokoh dalam cerita novel LP yang sudah difilmkan itu, pesan dalam cerita dapat lebih mudah ditangkap oleh para siswa sebagai penontonnya. Dengan demikian nilai-nilai karakter dapat ditanamkan kepada melalui menonton film tersebut (Baetenns 2007).

Film LP, sebagaimana novel aslinya menceritakan kisah anak-anak kampung dari komunitas Masyarakat Melayu di Bangka Belitong yang miskin. Kehidupan anak-anak miskin tersebut selalu dikontraskan dengan kehidupan serba ada dan berkecukupan dari sekelompok masyarakat pendatang dari perusahaan timah di Belitong yang modern dan multikultural. Anak-anak laskar pelangi yang miskin itu, mencoba memperbaiki nasib masa depannya dengan semangat kebersamaan dan kesetiakawanan. Melalui visual yang disajikan dalam film, semangat anak-anak miskin dari Bangka Belitong itu dapat tergambar dengan jelas. Masing-masing tokoh menunjukkan karakter yang kuat dalam semangat nasionalisme, kesetiakawanan dan kebersamaan dalam menjaga alam sekitar dan budaya masyarakatnya.

Tentu masih banyak film lain yang dapat digunakan sebagi materi dalam GLS di SD, yang bermanfaat untuk menanamkan nilai-nilai kehidupan, seperti sikap tanggung jawab, kejujuran, tolelaransi dalam konteks multikulturalisme, dan nilai-nilai karakter yang lainnya (Tonbuloglu et al. 2016). Namun melalui contoh film Laskar Pelangi itu setidaknya dapat dipahami bahwa film yang merupakan ekranisasi novel itu, sangat bagus digunakan sebagai media yang dapat meningkatkan motivasi dan prestasi belajar sekaligus membentuk karakter dalam menemukan jatidiri (Sugeng Riyadi 2014)(Tuller \& Or 2001).

Hal itu bisa dipahami, mengingat bahwa film adalah media yang efektif untuk menyampaikan berbagai pesan dan ideologi. Film tidak hanya memberikan presentasi visual untuk memudahkan penonton untuk memahami cerita, tetapi juga memungkinkan adanya kesan yang lebih mendalam dari cerita yang disajikan melalui gambar dan ekspresi para pemain sesai karakter tokoh dalam ceritanya (Stam \& Raengo 2008). 
Melalui contoh film LP yang dipilih dalam pengembangan buku pedoman GLS berbasis film ini dapat dilakukan penanaman karakter terhadap para siswa selama proses gerakan literasi di sekolah (Nugrahani 2017). Dengan demikian hal itu menunjukkan bahwa melalui program GLS berbasis film dapat dilakukan penanaman karakter siswa di sekolah.

\section{PENUTUP}

Berdasarkan temuan penelitian dan pembahasannya dapat disampaikan bahwa pendidikan karakter di SD dapat dilaksanakan melalui kegiatan literasi. Adapun kegiatan literasi tersebut akan dapat berjalan dengan dengan lancar jika dilaksanaan berdasarkan buku panduan yang baik dan teruji keefektifannya di lapangan. Untuk itu, buku panduan GLS berbasis film yang dikembangkan melalui penelitian ini merupakan salah satu alternative pedoman, yang dapat diimplementasikan dalam pendidikan karakter di sekolah melalui program GLS.

Buku panduan GLS berbasis film yang dikembangkan melalui penelitian ini telah diuji validitas, kepraktisan dan keefektivitasannya di sekolah. Adapun hasil ujinya menunjukkan bahwa buku panduan yang disusun termasuk dalam katagori baik, dan dapat dipakai atau diimplementasikan dalam pendidikan karakter di lapangan, meskipun masih memerlukan sedikit revisi. Sementara itu, nilai-nilai karakter yang dapat dikembangkan melalui kegiatan literasi berbasis film ini adalah semua pilar karakter yang telah ditetapkan oleh pemerintah. Namun, dari contoh film yang berjudul LP, yang umumnya digemari dan oleh anak-anak usia SD ini, nilai nilai karakter yang dapat dikembangkan adalah nilai-nilai yang berkaitan dengan rasa percaya diri (trustworthiness), kepedulian (caring), dan rasa kebangsaan (citizenship).

Berdasarkan temuan-temuan seperti yang telah diuraikan di atas, dapat disimpulkan bahwa buku pedoman GLS berbasis film yang telah disusun itu bersifat valid, dan praktis, sehingga efektif digunakan dalam GLS di Sekolah Dasar Pengkol 1 Sukoharjo. Melalui program GLS berbasis film itu, siswa menjadi lebih aktif dan antusias dalam mengikuti kegiatan dalam suasana yang menyenangkan. Selain itu, kegiatan GLS berbasis film ini sangat mendukung pembentukan karakter siswa, sesuai dengan pilar-pilar karakter yang telah ditetapkan pemerintah dalam program pendidikan karakter.

\section{UCAPAN TERIMA KASIH}

Pada kesempatan ini tim peneliti mengucapkan terima kasih kepada DRPM Ditjen Dikti dan LPPM Universitas Veteran Bangun Nusantara yang telah memberikan dana untuk pelaksanaan PTUPT ini. Disampaikan terima kasih pula kepada teman sejawat, Kepala Sekolah, guru, dan siswa di SD N Pengkol 1 Sukoharjo yang telah bersedia menjadi reviewer, narasumber, dan subjek dalam penelitian ini. Ucapan terima kasih juga disampaikan kepada Jurnal Belajar Bahasa Universitas Muhammadiyah 
Jember yang telah mempublikasikan artikel ilmiah hasil penelitian ini. Semoga bermanfaat.

\section{DAFTAR PUSTAKA}

Ardianto, D.T., 2014. Dari Novel ke Film : Kajian Teori Adaptasi sebagai Pendekatan dalam Penciptaan Film. Panggung Jurnal Seni Budaya, 24(1), pp.1-19.

Baetenns, J., 2007. From screen to text: novelization, the hidden continent. In The Cambridge Companion to Literature on Screen. Cambridge: Cambridge University Press, pp. 226238.

Davidson,

M., 2014.

A_character_education_research for 21st century.pdf. Journal of Character Education, 10(1), pp.77-83.

Dirjen Dikdasmen, 2016. Desain induk gerakan literasi sekolah. http://repositori.perpustakaan.kemdi kbud.go.id.

Faizah dkk, 2016. Panduan gerakan literasi sekolah di sekolah dasar 1st ed., Jakarta: Kemendikbud.

Graffy, J., 2011. Literature and film. In The Cambridge Companion to TwentiethCentury Russian Literature. Cambridge: Cambridge University Press., pp. 235-250.

Istadiyantha \& Wati, R., 2015. Ekranisasi Sebagai Wahana Adaptasi Dari Karya Sastra ke Film. Haluan Sastra dan Budaya, 1(1), pp.1-19.

Karkono, 2009. Perbedaan Makna Novel dan Film Ayat-Ayat Cinta: Kajian Ekranisasi. Atavisme, 12(2), p.167.
Lapsley, D.K. \& Yeager, D., 2013. Chapter: Moral-character education. Handbook of psychology, Vol. 7: Educational psychology (2nd ed.), pp.147-177.

Manullang, B., 2013. Grand Desain Pendidikan Karakter Generasi Emas 2045. Jurnal Pendidikan Karakter, 3(1), pp.1-14.

Nugrahani, F., 2017. The Development of Film-Based Literary Materials which Support Character Education. Cakrawala Pendidikan, XXXVI(3), pp.472-475.

Stam, R. \& Raengo, A., 2008. A Companion to Literature and Film 1st ed., Blackwell Publishing Ltd.

Sudrajat, A., 2011. Mengapa Pendidikan Karakter? Jurnal Pendidikan Karakter, 1(1), pp.47-57. Available at: https://doi.org/10.21831/jpk.v1i1.13 16.

Sugeng Riyadi, 2014. Penggunaan Film Adaptasi sebagai Media Pengajaran Sastra. bahasa \& sastra, Oktober 2014, 14(2), pp.241-251.

Suseno, 2013. Ekranisasi sebagai Sarana Eksistensi dan Politisasi Sastra Indonesia. In Yes UAD. UAD, pp. 213217.

Tonbuloglu, B., Aslan, D. \& Aydin, H., 2016. Teachers??? awareness of multicultural education and diversity in school settings. Egitim Arastirmalari - Eurasian Journal of Educational Research, (64), pp.1-28.

Tuller, M. \& Or, D., 2001. Hydraulic conductivity of variably saturated porous media: Film and corner flow in 
Farida Nugrahani, dkk. Pengembangan Model Pendidikan...

Jurnal Belajar Bahasa, ISSN 2502-5864, E-ISSN 2503-0329

Volume 4, No. 1, Februari 2019

angular pore space. Water Resources

Research, 35(5), pp.1257-1276.

Uricchio, W., 2014. Film, cinema, television ... media? New Review of Film and Television Studies, 12(3), pp.266-279.

Vardani, E.N., 2018. penanaman nilai nilai karakter. Belajar Bahasa Unmuh Jember, 3(1), pp.23-37 